\title{
ANALISIS KEMAMPUAN AWAL LITERASI SAINS MAHASISWA PADA KONSEP IPA
}

\author{
Anggun Winata, 'Sri Cacik, Ifa Seftia R. W. \\ FakultasKeguruandanIlmuPendidikan, Universitas PGRI RonggolaweTuban \\ Email: anggunwinata@gmail.com,sricacik@yahoo.co.id,ifaseftia@gmail.com
}

\begin{abstract}
Abstrak. Telah dilakukan penelitian yang bertujuan mengetahui kemampuan awal literasi sains mahasiswa PGSD UNIROW pada konsep IPA yang terdiri dari tujuh indikator yaitu 1) mengidentifikasi pendapat ilmiah yang valid 2) melakukan penelusuran literatur yang efektif 3) memahami elemen-elemen desain penelitian dan bagaimana dampaknya terhadap temuan/ kesimpulan 4) membuat grafik secara tepat dari data; 5) memecahkan masalah menggunakan keterampilan kuantitatif, termasuk statistik dasar; 6) memahami dan menginterpretasikan statistik dasar; 7) melakukan inferensi, prediksi, dan penarikan kesimpulan berdasarkan data kuantitatif. Studi ini merupakan bagian dari studi pengembangan perangkat pembelajaran untuk meningkatkan kemampuan literasi sains. Tes kemampuan literasi sains yang disusun berjumlah dua puluh lima butir soal. Kemampuan awal literasi sains yang dianalisis merupakan kemampuan literasi sains mahasiswa sebelum diterapkan suatu model yang diduga dapat mengembangkan kemampuan literasi sains mahasiswa. Hasil analisis menunjukkan bahwa kemampuan literasi sains mahasiswa yang lebih tinggi adalah indikator melakukan penelusuran literatur yang efektif dengan presentase sebesar 40,15\%. Sedangkan hasil analisis kemampuan literasi sains mahasiswa yang lebih rendah adalah indikator memecahkan masalah menggunakan keterampilan kuantitatif, termasuk statistik dasar dengan presentase sebesar 6,82\%. Hasil yang diperoleh sesuai dengan hasil surve PISA tahun 2003, 2006, 2009 dan 2012 serta hasil surve TIMSS tahun 2007dan 2011 Indonesia menunjukkan kemampuan dari siswa di Indonesia termasuk dalam kategori rendah.
\end{abstract}

Kata Kunci:Kemampuan awal, literasi sains, konsep IPA

Abstract. Has conducted research that aims to determine the ability of early scientific literacy of students PGSD UNIROW on the concept of IPA consists of seven indicators: 1) identify the scientific opinion is valid 2) perform literature searches were effectively 3) to understand the elements of research design and how it will impact the findings / conclusions 4) make precise graph of the data; 5) solve problems using quantitative skills, including basic statistics; 6) understand and interpret basic statistics; 7) perform inference, prediction, and drawing conclusions based on quantitative data. The study is part of a study of the development of learning tools to improve science literacy. Science literacy proficiency tests were arranged were twenty-five items. Initial capability analyzed scientific literacy is the ability of scientific literacy of students before applied a model that could be expected to develop the ability of science literacy of students. The analysis showed that the literacy skills of students of higher science is an indicator of effective literature searches with a percentage of $40.15 \%$. While the results of the analysis of the ability of scientific literacy of students lower is an indicator of solve problems using quantitative skills, including basic statistics with a percentage of $6.82 \%$. The results obtained in accordance with the results of surve PISA 2003, 2006, 2009 and 2012 and the results of the TIMSS surve 2007dan year 2011 Indonesia demonstrate the ability of students in Indonesia, including in the low category.

Keywords: Ability beginning, cience literacy, science concept 


\section{PENDAHULUAN}

Literasi sains dapat dijadikan sebagai indikator bagi kualitas pendidikan dan sumber daya manusia suatu negara. Hasil surve PISA tahun 2003 (OECD, 2003: 38-39) mendefinisikan pengertian literasi sains adalah kemampuan menggunakan pengetahuan sains, mengidentifikasi pertanyaan-pertanyaan, menarik kesimpulan berdasarkan bukti-bukti untuk memahami dan membantu membuat keputusan berkenaan tentang alam serta perubahan yang dilakukan terhadap alam melalui aktivitas manusia. Menurut NCES (2012: 1), literasi sains adalah pengetahuan dan pemahaman konsep serta proses ilmiah yang diperlukan untuk membuat keputusan personal, berkontribusi dalam kegiatan kebudayaan dan kemasyarakatan, serta produktivitas ekonomi. Sedangkan menurut Gormally et al. (2012: 364), literasi sains diartikan sebagai kemampuan seseorang untuk membedakan fakta-fakta sains dari bermacammacam informasi, mengenal dan menganalisis penggunaan metode penyelidikan saintifik serta kemampuan untuk mengorganisasi, menganalisis, menginterpretasikan data kuantitatif dan informasi sains.Berdasarkan beberapa pendefinisian literasi sains, maka literasi sains dipandang multidimensional yang tidak hanya pemahaman terhadap pengetahuan sains (OECD, 2009: 12).

Dibandingkan dengan negara-negara di Asia lainnya, Indonesia termasuk dalam urutan di bawah terkait kemapuan literasi sains. Hasil surve yang dilakukan oleh Programme for International Student Assessment (PISA)menunjukkan skorliterasisainspeserta didik Indonesia berturut-turutadalah 393, 395, 395 untuktahun 2000, 2003, dan 2006(Bybeeet al., 2009: 5).Hasil survey PISA 2009 menunjukkan skorliterasi sains Indonesia mencapai 383 dan masuk urutan 57 dari 65 negara (Walker,2011: 105).Hasil survey PISA tahun 2012menunjukkan skorliterasi sains Indonesia yaitu 382 dan masukurutan 63 dari 64 negara
(OECD, 2013: 67). Sejalan dengan hasil PISA, berdasarkan survey yang diselenggarakan oleh Trends in International Mathematics and Science Study (TIMSS) yang dilakukan setiap empat tahun sekali pada tahun 2007 Indonesia berada di peringkat ke 35 dari 49 negara dan tahun 2011 Indonesia berada di peringkat 40 dari 42 negara (NCES, 2012: 3). Hasil ini menunjukkan bahwa skor rata-rata literasi sains Indonesia berada di bawah rata-rata skor Internasional dan harus segera untuk diatasi.

Tujuan pelaksanaan evaluasi pendidikan oleh OECD melalu PISA dan NCES melalui TIMSS adalah memperbaiki kualitas pendidikan. Perbaikan kualitas pendidikan akan berpengaruh pada tingkat ekonomi negara-negara anggota. Seperti yang kita ketahui negara-negara yang memiliki prestasi yang baik pada evaluasi PISA ratarata memiliki perekonomian dan teknologi yang maju.

PISA menetapkan tiga aspek dari komponen kompetensi/proses sains. Tiga kompetensi ilmiah yang diukur dalam literasi sains. Ketiga kompetensi tersebut yaitu Pertama, mengidentifikasi isu-isu (masalah) ilmiah yaitu mengenali masalah yang mungkin untuk penyelidikan ilmiah, mengidentifikasi kata kunci untuk mencari informasi ilmiah, mengenali fitur kunci dari penyelidikan ilmiah. Kedua, menjelaskan fenomena ilmiah yaitu menerapkan ilmu pengetahuan dalam situasi tertentu, menggambarkan atau menafsirkan fenomena ilmiah dan memprediksi perubahan, mengidentifikasi deskripsi yang tepat, memberikan penjelasan, dan prediksi. Ketiga, menggunakan bukti ilmiah yaitu menafsirkan bukti ilmiah dan membuat kesimpulan dan mengkomunikasikan, mengidentifikasi asumsi, bukti, dan alasan di balik kesimpulan, berkaca pada implikasi sosial dari ilmu pengetahuan dan perkembangan teknologi (Bybee, 2009: 5). 
Untuk mengkategorikan kemampuan siswa dalam literasi sains maka digunakan tujuh indikator dalam menentukan kemampuan literasi sains. Ketujuh indikator tersebut merujuk dari indikator kemampuan literasi sains dari Gormally et al. (2012). Ketujuh pengukuran indikator literasi sains tersebut yaitu (1) mengidentifikasi pendapat ilmiah yang valid (2) melakukan penelusuran literatur yang efektif (3) memahami elemenelemen desain penelitian dan bagaimana dampaknya terhadap temuan/ kesimpulan (4) membuat grafik secara tepat dari data; (5) memecahkan masalah menggunakan keterampilan kuantitatif, termasuk statistik dasar; (6) memahami dan menginterpretasikan statistik dasar; (7) melakukan inferensi, prediksi, dan penarikan kesimpulan berdasarkan data kuantitatif. Indikator kemampuan literasi sains yang dikembangkan oleh Gormally et al. (2012: 365) dipilih karena sangat sederhana, muda diimplementasikan dan telah mencerminkan dari kemampuan literasi sains. Selain itu, ketiga indikator tersebut termuat dalam tiga kompetensi ilmiah yang diukur dalam literasi sains. Mengidentifikasi isu-isu (masalah) ilmiah ada pada indikator 1, menjelaskan fenomena ilmiah ada pada indikator 2 sampai 6 , dan menggunakan bukti ilmiah ada pada indikator 7 .

\section{METODE}

$\begin{array}{llr}\text { Jenis } & \text { penelitian adalah penelitian } \\ \text { deskriptif } & \text { yang bertujuan } & \text { untuk }\end{array}$

mendeskripsikan kemampuan awal literasi sains mahasiswa Prodi PGSD UNIROW. Jenis penelitian digunakan untuk mengambarkan perbandingan antara kemampuan awal literasi sains mahasiswa dengan ketujuh pengukuran indikator literasi sains yaitu 1) mengidentifikasi pendapat ilmiah yang valid 2) melakukan penelusuran literatur yang efektif 3) memahami elemen-elemen desain penelitian dan bagaimana dampaknya terhadap temuan/ kesimpulan 4) membuat grafik secara tepat dari data; 5) memecahkan masalah menggunakan keterampilan kuantitatif, termasuk statistik dasar; 6) memahami dan menginterpretasikan statistik dasar; 7) melakukan inferensi, prediksi, dan penarikan kesimpulan berdasarkan data kuantitatif. Penelitian dilakukan pada bulan Desember 2016 di Prodi PGSD UNIROW. Subjek penelitian adalah mahasiswa Prodi PGSD UNIROW angkatan 2016. Kemampual awal literasi sains diketahui dari hasil pengerjaan soal tes kemampuan literasi sains kemudian dianalisis persentase jawaban mahasiswayang benar sesuai dengan indikator yang diadaptasi Gormally et al. (2012).

\section{HASIL DAN PEMBAHASAN}

Tahapan awal dari penelitian adalah penyusunan tes kemampuan literasi sains dan menggunakan indikator yang diadaptasi dari Gormally et al. (2012). Adapun Gambaran umum atau kategori kemampuan literasi sains yang disusun seperti Tabel 1. 
Tabel 1. Gambaran Umum Kategori dan Indikator Literasi Sains Mahasiswa

\begin{tabular}{|c|c|c|c|}
\hline No & $\begin{array}{c}\text { Kopetensi Ilmiah yang Diukur } \\
\text { dalam Literasi Sains }\end{array}$ & & Indikator \\
\hline 1 & $\begin{array}{l}\text { Mengidentifikasi isu-isu (masalah) } \\
\text { ilmiah }\end{array}$ & 1 & $\begin{array}{l}\text { Mengidentifikasi pendapat ilmiah yang valid (misalnya } \\
\text { pendapat/teori untuk mendukung hipotesis) }\end{array}$ \\
\hline \multirow[t]{5}{*}{2} & Menjelaskan fenomena ilmiah & 2 & $\begin{array}{l}\text { Melakukan penelusuran literatur yang efektif (misalnya } \\
\text { mengevaluasi validitas sumber dan membedakan diantara } \\
\text { tipe sumber-sumber tersebut) }\end{array}$ \\
\hline & & 3 & Memahami elemen-elemen dalam desain penelitian \\
\hline & & 4 & Membuat grafik secara tepat dari data \\
\hline & & 5 & $\begin{array}{l}\text { Memecahkan masalah menggunakan keterampilan } \\
\text { kuantitatif, termasuk statistik dasar (misalnya menghitung } \\
\text { rata-rata, probabilitas, persentase, frekuensi) }\end{array}$ \\
\hline & & 6 & $\begin{array}{l}\text { Memahami dan menginterpretasikan statistik dasar } \\
\text { (menginterpretasi kesalahan, memahami kebutuhan untuk } \\
\text { analisis statistik) }\end{array}$ \\
\hline 3 & Menggunakan bukti ilmiah & 7 & $\begin{array}{l}\text { Melakukan inferensi, prediksi, dan penarikan kesimpulan } \\
\text { berdasarkan data kuantitatif }\end{array}$ \\
\hline
\end{tabular}

Hasil tes kemampuan literasi sains mahasiswa menunjukkan bahwa kemampuan literasi sains mahasiswa yang lebih tinggi adalah indikator melakukan penelusuran literatur yang efektif dengan presentase sebesar 40,15\%. Sedangkan hasil analisis kemampuan literasi sains mahasiswa yang lebih rendah adalah memecahkan masalah menggunakan keterampilan kuantitatif, termasuk statistik dasar dengan presentase sebesar 6,82. Secara lengkap kemampuan literasi sains mahasiswa setiap indikator dapat dilihat pada Gambar 1.

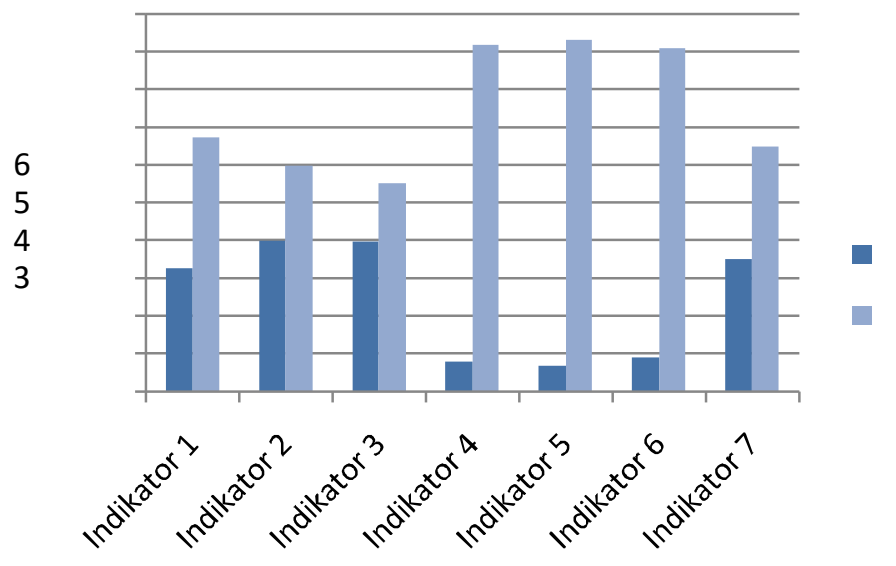

Gambar 1. Hasil Jawaban Mahasiswa pada tes Kemampuan Awal Literasi Sains.

Pada Gambar 1 menunjukkan bahwa (6) indikator 4 yaitu sebesar 8,08\% dan (7) persentase jawaban mahasiswa benar dari yang indikator 5 yaitu sebesar $6,82 \%$. Secara umum paling tinggi ke paling rendah berturut-turut dari seluruh Gambar 1 menunjukkan bahwa adalah (1) indikator 2 yaitu sebesar 40,15\%, (2) sebagian besar mahasiswa Prodi PGSD Unirow indikator 3 yaitu 39,77\%, (3) indikator 7 yaitu angkatan 2016 cenderung masih memiliki sebesar 35, 10\%, (4) indikator 1 yaitu sebesar kemampuan literasi sains yang masih rendah $32,68 \%$, (5) indikator 6 yaitu sebesar 9,09\%, yaitu kurang dari 50\% untuk masing-masing 
indikator. Berdasarkan kategori kemapuan literasi sains, menunjukkan bahwa kemampuan menjelaskan fenomena ilmiah masih rendah terlihat dari dua indikator dari lima indikator dalam kategori tersebut yang menunjukkan hasil sangat kecil yaitu dibawah $10 \%$. Sejalan dengan itu hasil dari ketegori menggunakan bukti ilmiah juga menunjukkan hasil yang sangat rendah yaitu dibawah $10 \%$.

Ketidakmampuan mahasiswa dalam kemampuan menjelaskan fenomena ilmiah dan menggunakan bukti ilmiah menunjukkan bahwamahasiswa belum mampumemecahkan masalah secara ilmiah dan mengkomunikasikan hasil-hasil percobaan yang dilakukan secara tertulis. Ketidakmampuan mahasiswa tersebutmenunjukkan bahwa pembelajaran sains atau IPA di PGSD UNIROW masih belum dilaksanakan sesuai hakikat sains.

Secara keseluruhan kemampuan literasi sains mahasiswa mempunyai kemampuan literasi sains yang rendah. Hal ini ditunjukkan dari hasil soal tes kemampuan literasi sains mahasiswa hanya dapat menentukan masalah tetapi tidak dapat memberikan penjelasan secara ilmiah. Beberapa faktor yang menjadi penyebab antara lain mahasiswabelum terbiasa dalam menyelesaikan tes kemampuan literasi sains ataumasalah yang berhubungan dengan keterampilan proses sains yang merupakan bagian utama literasi sains.

Berdasarkan hasil analisis kemampuan awal literasi mahasiswa Prodi PGSD UNIROW maka perlu adanya pembelajaran yang dapat melatihkan keterampilan-keterampilan proses sains sehingga siswa terbiasa melakukan halhal yang berhubungan dengan kegiatan diantaranya: mengidentifikasi pertanyaan ilmiah, memberikan penjelaskan fenomena secara ilmiah dan menggunakan bukti ilmiah. Menurut Diana et al., (2015), agar kemampuan literasi sains dapat meningkat dengan baik, maka para pengajar dihimbau untuk mulai memperkenalkan dan membelajarkan materi dengan menggunakan berbagai strategi yang beraspek literasi sains, antara lain membelajarkan materi melalui eksperimen yang dapat merangsang berpikir tingkat tinggi dan bersifat kontekstual. Menurut Rizkitaet al., (2016:780), peningkatan kemampuan literasi sains dapat dilakukan melalui pembelajaran yang menekankan pada kemampuan problem solvingyang dapat dilakukan dengan strategi Problem-Based Learning (PBL). Sejalan dengan itu, Trowbridge \& Bybee (1996) merekomendasikan model pembelajaran siklus belajar dalam melatihkan kemampuan literasi sains.

\section{SIMPULAN}

Berdasarkan hasil penelitian dan analisis data, yang diperoleh dari penelitian ini, maka dapat disimpulkan bahwa hasil analisis menunjukkan bahwa kemampuan literasi sains mahasiswa yang lebih tinggi adalah indikator melakukan penelusuran literatur yang efektif dengan presentase sebesar 40,15\%. Sedangkan hasil analisis kemampuan literasi sains mahasiswa yang lebih rendah adalah indikator memecahkan masalah menggunakan keterampilan kuantitatif, termasuk statistik dasar dengan presentase sebesar 6,82\%.Adapun solusi yang dapat ditawarkan adalah perlunya pembelajaran melalui eksperimen, strategi Problem-Based Learning (PBL) dan model pembelajaran siklus belajar.

\section{DAFTAR PUSTAKA}

Bybee, R. W. 2009. PISA'S 2006 Measurement of Scientific Literacy: An Insider's Perspective for the U.S. A Presentation for the NCES PISA Research Conference. Washington: Science Forum and Science Expert Group.

Diana, S., Arif, R., Euis, S. R. 2015. Profil Kemampuan Literasi Sains Siswa SMA Berdasarkan Instrumen Scientific Literacy Assesments (SLA). Seminar Nasional XII Pendidikan Biologi FKIP UNS 201. 
Gormally, C., Peggy B., \& Mary L., 2012.Developing a Test of Scientific Literacy Skills (TOLS): Measuring Undergraduates 'Evaluation of Scientific Information and Arguments. CBE-Life Sciences Education, 11 (2012), 364-377.

National Center for Education Statistics (NCES). 2012. Highlights From TIMSS 2007: Mathematics and Science Achievement of U.S. Fourthand EighthGrade Students in an International Context. Washington, DC : U.S. Department of Education.

OECD. 2003. First Results from Pisa 2003: OECD Publishing.

OECD. 2009. A Framework for PISA: Assessing Scientific, Reading, and Mathematical Literacy: OECD Publishing.

OECD. 2013. Survey International Program for International Student Assessment (PISA). (Online) (http: // www.oecd.org/pisa), diakses 01 Juni 2015.

Rizkita L., Suwono, H., \& Susilo. H. 2016. Analisis Kemampuan Awal Literasi Sains Siswa Sma Kota Malang. Seminar Nasional II Kerjasama Prodi Pendidikan Biologi FKIP dengan Pusat Studi Lingkungan dan Kependudukan (PSLK) Universitas Muhammadiyah Malang

Trowbridge, L. W., \& Bybee, R. W. 1996. Teaching Secondary Schooll Science Strategies For Developing Scientific Literacy. Englewood; New Jersey; Columbus; Ohio: Merrill an Imprint of Prentice Hall.

Walker, M. 2011. PISA 2009 Plus Results : Performance of 15-year-olds in reading, mathematics and science for 10 additional participants. Melbourne: ACER Press 